\title{
PENGARUH RELIGIUSITAS, PEMAHAMAN PERPAJAKAN, STATUS SOSIAL EKONOMI DAN LOVE OF MONEY TERHADAP PERSEPSI PENGGELAPAN PAJAK
}

\author{
Friska Ade Nauvalia, Yuniarti Hermawan ${ }^{2}$ \\ ${ }^{1}$ Program Studi Akuntansi, ${ }^{2}$ Program Studi Manejemen Perpajakan \\ Fakultas Ekonomi Universitas Pancasakti
}

\begin{abstract}
This study aims to examine the influence of religiusity, understanding taxation, socioeconomic status and love of money on the perception of tax evasion simultaneously and partially. Population in this study are accounting studens of economic faculty at the university of pancasakti tegal force of 2014 and 2015, with a sample of 81 students. Sampling technique used in this research in purposive sampling technique. The results of the analysis using computerized calculations with SPSS program version 22 which shows that religiosity, understanding taxation, socioeconomic status and love of money affect simultaneously to perceptions of tax evasion. Religusitas and socioeconomic status does not partially affect the perception of tax evasion. instead this study shows the understanding of taxation and love of money partially influence the perception of tax evasion.
\end{abstract}

Keyword : of religiosity, understanding taxation, socioeconomic status, love of money and tax evasion perceptions.

\section{PENDAHULUAN}

Pajak bisa dikatakan suatu kontribusi wajib kepada negara yang terutang oleh orang pribadi atau badan dan bersifat memaksa berdasarkan Undang-Undang, dengan tidak mendapatkan imbalan secara langsung dan digunakan untuk keperluan negara demi kelangsungan dan kemakmuran rakyat. Maka dari itu, warga negara indonesia tidak dapat melanggar kewajiban dan tanggung jawabnya untuk membayar pajak. Membayar pajak merupakan perwujudan, kewajiban dan peran bagi warga negara dalam pembiayaan negara dan pembangunan nasional. Dalam hal ini warga negara dapat dikatakan ikut serta berpartisipasi dalam pembiayaan pembangunan nasional negara (Mardiasmo 2013:1).
Target pencapaian pajak menjadi celah bagi para oknum petugas pajak, wajib pajak dan konsultan pajak untuk bekerja sama dalam tindakan kejahatan dan kecurangan dibidang perpajakan seperti penggelapan, penghindaran, penyimpangan, pemerasan dan pemalsuan dokumen yang tujuannya untuk mendapatkan keuntungan illegal sebesar-besarnya dan memperkaya diri sendiri sehingga pada akhirnya menyebabkan distorsi penerimaan atau kekayaan negara (Zirman, 2015).

Salah satu tindakan penggelapan pajak (Tax Evasion) tidak hanya sepenuhnya kesalahan wajib pajak. Peran oknum petugas pajak pun ikut mendukung atas tindakan kecurangan tersebut. Tingkat kepercayaan masyarakat pada profesi akuntansi telah mengalami penurunan, karena banyak 
terjadinya kasus skandal yang mencoreng profesi akuntansi sehingga mengakibatkan masyarakat meningkatkan perhatiannya untuk mengatasi isu-isu atau kasus-kasus skandal yang berdampak terhadap profesi (Basri, 2015).

Terjadinya krisis kepercayaan oleh masyarakat kepada para profesional akuntan, maka pendidikan etika harus benar-benar diterapkan dan diperhatikan dalam bangku perkuliahan dengan harapan mahasiswa mempunyai karakteristik yang menjunjung nilai-nilai etika dan menjadi individu yang beretika sebelum nantinya memasuki dunia kerja (Aziz, 2015).

Berdasarkan ulasan tersebut, rumusan masalah dalam penelitian sebagai berikut : Apakah ada pengaruh religiusitas, pemahaman perpajakan, status sosial ekonomi, dan love of money secara simultan dan parsial berpengaruh terhadap persepsi penggelapan pajak. Tujuan dari penelitian ini adalah mengetahui apakah ada pengaruh religiusitas, pemahaman perpajakan, status sosial ekonomi, dan love of money secara simultan dan parsial berpengaruh terhadap persepsi penggelapan pajak

\section{KERANGKA PEMIKIRAN DAN HIPOTESIS}

Pengaruh religiusitas, pemahaman perpajakan, status sosial ekonomi dan love of money secara simulan terhadap persepsi penggelapan pajak.

Dalam Ardiansyah, 2017 (Hakim, 2004:4) menjelaskan bahwa "Religiusitas itu adalah sikap hidup seseorang berdasarkan pada nilai-nilai yang diyakininya". Dilihat dari tingkat kepercayaan dan ketaatan terhadap agama semakin tingginya tingkat religiuisitas maka akan semakin rendah tingkat prosentase penggelapan pajak.
Hal ini didukung karena penggelapan pajak merupakan suatu kegiatan yang menyimpang dari norma agama (Basri, 2015).

Melalui pendidikan ataupun pengalaman, seseorang dapat memperoleh pengetahuan (viega, 2017). Seseorang harus memiliki pengetahuan perpajakan agar timbul kesadaran mengenai pajak dan untuk meningkatkan tingkat pemahaman mengenai pajak (Dharma, 2016). Semakin tinggi status sosial seseorang akan tinggi juga tingkat pemahaman tentang perpajakan, dan sebaliknya. Seseorang yang mengerti tentang peraturan dan tata cara perpajakan secara jelas termasuk wajib pajak yang patuh (Dharma, 2016). Jika tingkat pemahaman tentang perpajakan masih rendah maka cenderung dapat menyebabkan praktek penggelapan pajak yang dapat merugikan banyak pihak.

Love of money atau kecintaan terhadap uang merupakan salah satu alasan seseorang melakukan penggelapan pajak. Alasannya karena ketika seseorang menempatkan uang sebagai prioritas utama dalam suatu kehidupan sehari-harinya, mereka berfikir bahwa tindakan penggelapan pajak merupakan tindakan yang dapat diterima (Rosianti dan Yenny Mangoting, 2014). Tingkat kecintaan terhadap uang akan membuat semua kegiatan bernilai positif, karena uang merupakan sumber utama dalam kehidupan. Dalam kehidupan manusia sehari-hari tidak dapat terlepas dari uang, karena uang merupakan salah satu aspek yang sangat penting dalam kehidupan sehari-hari. Aziz (2015) berpendapat bahwa di Amerika serikat, kesuksesan diukur dengan uang dan pendapatan, akan tetapi sebagian orang menganggapnya berbeda.

H1 : Diduga religiusitas, pemahaman perpajakan, status sosial ekonomi dan love of 
money berpengaruh secara simultan terhadap persepsi penggelapan pajak.

Pengaruh religiusitas terhadap persepsi penggelapan pajak

Dalam Dharma (2016) menjelaskan bahwa etika penggelapan pajak dari cara pandang islam dan mentakan penggelapan pajak itu bisa juga beretika, kalau dilihat dari kondisi sekarang yaitu masih belum banyak realisasi pemerintah yang diterapkan kepada masyarakat, hal ini yang membuat masyarakat enggan untuk membayar pajak. Religiusitas memiliki pengaruh yang baik pada sikap dan perilaku manusia. Religiusitas merupakan nilai penting dalam struktur kognitif individu wajib pajak yang dapat mempengaruhi perilaku individu.

$\mathrm{H} 2$ : Diduga religiusitas

berpengaruh secara parsial terhadap persepsi penggelapan pajak.

Pengaruh pemahaman perpajakan terhadap persepsi penggelapan pajak

Pengaruh pemahaman perpajakan oleh mahasiswa akuntansi terhadap persepsi penggelapan pajak dapat dikembangkan dengan melihat seberapa besar pemahaman ketentuan perpajakan dapat dipahami oleh mahasiswa akuntansi, dimengerti dan dipatuhi untuk kemudian dilaksanakan. Tujuannya agar harapannya ke depan praktik penggelapan pajak dapat diminimalisir serendah mungkin dan mahasiswa akuntansi memahami perilaku tersebut melanggar hukum dan tidak etis untuk dilakukan. Hal ini juga didukung dalam penelitian Dharma (2016) yang menyatakan bahwa pengetahuan perpajakan memiliki pengaruh terhadap persepsi penggelapan pajak pada mahasiswa akunansi.
H3 : Diduga pemahaman per-

pajakan berpengaruh secara parsial terhadap persepsi penggelapan pajak.

Pengaruh status sosial ekonomi terhadap persepsi penggelapan pajak

Semakin meningkatnya status sosial ekonomi semakin tinggi pula tingkat penggelapan pajak. Henslin (2007:92) menyatakan "Untuk memahami orang, kita harus mempelajari lokasi sosial yang mereka tempati dalam kehidupan. Yang paling berperan adalah kelas sosial yang disadarkan pada penghasilan, pendidikan, dan prestasi kerja". Kelas sosial yang telah terbentuk dapat memberikan pengaruh pada ide dan sikap.

H4 : Diduga status sosial
ekonomi berpengaruh secara
parsial terhadap persepsi
penggelapan pajak.

Pengaruh love of money terhadap persepsi penggelapan pajak

Tang, 1992 (dalam Noviani dan Andri, 2014:Vol.3) memperkenalkan konsep the love of money sebagai sebuah literatur psikologis. Konsep tersebut digunakan untuk memperkirakan perasaan subjektif seseorang tentang uang. Kecintaan seseorang terhadap uang berbeda tergantung pada kebutuhan yang mereka miliki dan dipengaruhi oleh beberapa hal antara lain jenis kelamin, usia, tingkat pendidikan, status sosial ekonomi, dan ethnic background. Basri (2015) menyatakan bahwa sifat love of money atau cinta uang yang tinggi maka persepsi etika penggelapan pajak juga tinggi.

H5 : Diduga love of money berpengaruh secara parsial terhadap persepsi penggelapan pajak. 


\section{METODE PENELITIAN}

Metode yang digunakan dalam penelitian ini adalah metode deskriptif dengan pendekatan kuantitatif yaitu pengumpulan data yang berupa angka untuk diuji hipotesisnya atau menjawab pertanyaan mengenai status terakhir dari subjek penelitian (Kuncoro, 2013:12).

Populasi dalam penelitian ini adalah mahasiswa S1 program studi akuntansi Fakultas Ekonomi dan Bisnis Universitas Pancasakti Tegal. Teknik pengambilan sampel ditentukan berdasarkan purposive sampling yaitu metode yang sengaja digunakan karena informasi yang diambil berasal dari sumber yang dipilih berdasarkan kriteria tertentu (Kuncoro, 2013:118).

Besarnya sampel dalam penelitian ini ditentukan menggunakan rumus slovin sehingga diemukan sampel sejumlah 81 responden.

Teknik analisis data yang digunakan adalah Analisis Statistik Deskriptif, uji reliabilias, uji validias, Analisis Regresi Linier Berganda, Uji Hipotesis meliputi Uji F, Uji t, dan Koefisien determinasi.

Tabel 3.1 Definisi Konseptual dan Operasional Variabel

\begin{tabular}{|c|c|c|c|c|c|}
\hline Variabel & Dimensi & Indikator & Pengukuran & Skala & $\begin{array}{c}\text { Item } \\
\text { pertanyaa }\end{array}$ \\
\hline $\begin{array}{l}\text { Penggelapan } \\
\text { Pajak (tax } \\
\text { evasion) } \\
\text { (Ardiansyah, } \\
\text { 2017) dan } \\
\text { (Permata } \\
\text { Bahari, 2016) }\end{array}$ & $\begin{array}{l}\text { Pemahaman } \\
\text { tentang } \\
\text { penggelapan } \\
\text { pajak }\end{array}$ & $\begin{array}{l}\text { Penyebab } \\
\text { penggelapan pajak } \\
\text { Sistem pengelolaan } \\
\text { keuangan } \\
\text { perpajakan } \\
\text { Pengetahuan } \\
\text { penggelapan } \\
\text { pajak }\end{array}$ & Likert & Interval & $\begin{array}{l}1,5 \\
2 \\
3,4\end{array}$ \\
\hline $\begin{array}{l}\text { Religiusitas } \\
\text { (Ardiansyah, } \\
\text { 2017) }\end{array}$ & $\begin{array}{l}\text { Kepercayaan } \\
\text { dan ketaatan }\end{array}$ & $\begin{array}{l}\text { Ideologi } \\
\text { Praktek Ibadah } \\
\text { Pengalaman } \\
\text { Pengetahuan } \\
\text { Agama } \\
\text { Konsekuensi }\end{array}$ & Likert & Interval & $\begin{array}{l}1 \\
2,7 \\
6 \\
3\end{array}$ \\
\hline $\begin{array}{l}\text { Pemahaman } \\
\text { Perpajakan } \\
\text { (Ardiansyah, } \\
\text { 2017) dan } \\
\text { (Permata } \\
\text { Bahari, 2016) }\end{array}$ & $\begin{array}{l}\text { Pengetahuan } \\
\text { tentang } \\
\text { ketentuan dan } \\
\text { tata cara } \\
\text { perpajakan }\end{array}$ & $\begin{array}{l}\text { Pemahaman } \\
\text { sistem } \\
\text { perpajakan } \\
\text { Pemahaan } \\
\text { persyaratn } \\
\text { perpajakn }\end{array}$ & Likert & Interval & $2,3,4,5$ \\
\hline $\begin{array}{l}\text { Status Sosial } \\
\text { Ekonomi }\end{array}$ & $\begin{array}{l}\text { Pendapatan } \\
\text { ekonomi }\end{array}$ & Tingkat penghasilan & Dummy & Nominal & - \\
\hline $\begin{array}{l}\text { Love of } \\
\text { Money } \\
\text { (Aziz, 2015) }\end{array}$ & $\begin{array}{l}\text { Kepuasan } \\
\text { mengelola uang }\end{array}$ & $\begin{array}{l}\text { Anggaran } \\
\text { Adil } \\
\text { Sukses } \\
\text { Ekspresi } \\
\text { Diri } \\
\text { Pengaruh Sosial }\end{array}$ & Likert & Interval & $\begin{array}{l}1,4, \\
2, \\
6, \\
3, \\
8, \\
5,7,9,10\end{array}$ \\
\hline
\end{tabular}




\section{Penggelapan Pajak (Y)}

Chairil Anwar (2013:23) Penyelundupan atau penggelapan pajak (Tax Evasion) adalah upaya wajib pajak menghindari pajak terutang secara ilegal dengan cara menyembunyikan keadaan yang sebenarnya.

\section{Religiusias (x1)}

Dalam Ardiansyah, 2017 (Hakim, 2004:4) menjelaskan bahwa "Religiusitas itu adalah sikap hidup seseorang berdasarkan pada nilai-nilai yang diyakininya". Sedangkan menurut (Agus, 2000:6) "ekspresi religius ditemukan dalam budaya material, perilaku manusia, nilai, moral, hukum dan sebagainya. Tidak ada aspek kebudayaan lain dari agama yang lebih luas pengaruh dan implikasinya dalam kehidupan manusia".

\section{Pemahaman Perpajakan (x2)}

Dharma (2016) mengatakan bahwa pengetahuan dan pemahaman akan peraturan perpajakan adalah proses dimana wajib pajak memahami tentang perpajakan dan menerapkan pengetahuan untuk membayar pajak. Syarat-syarat untuk melakukan pembayaran pajak adalah wajib pajak harus memiliki NPWP (Nomor Pokok Wajib Pajak) dan wajib pajak harus melaporkan SPT (Surat Pemberitahuan) baik masa maupun tahunan.

\section{Status Sosial Ekonomi (x3)}

Rahayu (2017), menjelaskan bahwa status sosial ekonomi dapat dipahami dengan melihat asal katanya. Kata sosial berasal dari kata "socius" yang artinya kawan (teman). Dalam hal ini arti kawan bukan terbatas sebagai teman sepermainan, teman kerja dan sebagainya. Yang dimaksud teman adalah mereka yang ada disekitar kita, yakni yang tinggal dalam satu lingkungan tertentu dan mempunyai sifat yang saling mempengaruhi. Sedangkan istilah ekonomi berasal dari bahasa
Yunani yaitu "oikos" yang artinya rumah tangga dan "nomos" yang artinya mengatur, jadi secara harafiah ekonomi berarti cara mengatur rumah tangga.

Sosial ekonomi dapat juga diartikan sebagai suatu keadaan atau kedudukan yang diatur secara sosial dan menetapkan seseorang dalam posisi tertentu dalam struktur masyarakat. Pemberian posisis ini disertai pula seperangkat hak dan kewajiban yang harus dipenuhi sipembawa status misalnya, pendapatan, dan pekerjaan.

\section{Love Of Money (x4)}

Noviani dan Andri(2014:Vol.3) memperkenalkan konsep the love of money sebagai sebuah literatur psikologis. Konsep tersebut digunakan untuk memperkirakan perasaan subjektif seseorang tentang uang. Kecintaan seseorang terhadap uang berbeda tergantung pada kebutuhan yang mereka miliki dan dipengaruhi oleh beberapa hal antara lain jenis kelamin, usia, tingkat pendidikan, status sosial ekonomi, dan ethnic background.

Dari penjelasan diatas terkait dengan bagaimana sikap seseorang terhadap uang, jika seseorang menilai tinggi uang atau sangat mencintai uang, maka seseorang akan mengejar uang dan cenderung untuk melakukan berbagai cara untuk mendapatkan uang lebih banyak baik dengan cara yang etis maupun tidak etis, sebaliknya orang yang menilai rendah terhadap uang tidak terlalu bernafsu untuk mendapatkan uang yang banyak.

\section{HASIL}

Statistik deskriptif: Analisis deskriptif bertujuan untuk menunjukkan gambaran atau deskripsi suatu data yang dilihat dari nilai rata-rata (mean), maksimum, minimum, standar deviasi, dll (Ghozaly 2016 : 19). 
Tabel 4.1 Descriptive Statistics

\begin{tabular}{|c|c|c|c|c|c|}
\hline & $\mathrm{N}$ & Minimum & Maximum & Mean & $\begin{array}{l}\text { Std. } \\
\text { Deviation }\end{array}$ \\
\hline Religiusitas & 81 & 21,00 & 35,00 & 28,9630 & 2,93873 \\
\hline Pemahaman Perpajakan & 81 & 13,00 & 25,00 & 19,4444 & 3,42418 \\
\hline $\begin{array}{l}\text { Status Sosial Ekonomi } \\
\text { Love of Money }\end{array}$ & 81 &, 00 & 2,00 & ,3210 &, 73870 \\
\hline Penggelapan Pajak & 81 & 28,00 & 49,00 & 39,7160 & 5,44801 \\
\hline Valid N (listwise) & 81 & 13,00 & 25,00 & 19,8642 & 3,01145 \\
\hline
\end{tabular}

Sumber : Olah Data SPSS Versi 22

Berdasarkan uji statistik deskriptif diatas, dapat diketahui bahwa data penelitian ini sebanyak 81 responden. Berikut ini keterangan dari hasil statistik deskriptif yang telah diolah sebagai berikut :

Nilai mean dan standar deviasi yang dimiliki variabel religiusitas adalah 28,96 dan 2,93. Maka nilai rata-rata lebih besar dari nilai standar deviasinya. Hal ini menunjukkan bahwa kualitas data dari variabel religiusitas dalam penelitian ini baik, sebab nilai rata-rata lebih besar dari nilai standar deviasinya.

Nilai mean dan standar deviasi yang dimiliki variabel pemahaman perpajakan adalah 19,44 dan 3,42. Maka nilai rata-rata lebih besar dari nilai standar deviasinya. Hal ini menunjukkan bahwa kualitas data dari variabel pemahaman perpajakan dalam penelitian ini baik, sebab nilai rata-rata lebih besar dari nilai standar deviasinya.

Nilai mean dan standar deviasi yang dimiliki variabel status sosial ekonomi adalah 0,32 dan 0,72. Maka nilai rata-rata lebih kecil dari nilai standar deviasinya. Hal ini menunjukkan bahwa kualitas data dari variabel status sosial ekonomi dalam penelitian ini buruk, sebab nilai rata-rata lebih kecil dari nilai standar deviasinya.
Nilai mean dan standar deviasi yang dimiliki variabel love of money adalah 39,71 dan 5,44. Maka nilai rata-rata lebih besar dari nilai standar deviasinya. Hal ini menunjukkan bahwa kualitas data dari variabel love of money dalam penelitian ini baik, sebab nilai rata-rata lebih besar dari nilai standar deviasinya.

Nilai mean dan standar deviasi yang dimiliki variabel penggelapan pajak adalah 19,86 dan 3,01. Maka nilai rata-rata lebih besar dari nilai standar deviasinya. Hal ini menunjukkan bahwa kualitas data dari variabel penggelapan pajak dalam penelitian ini baik, sebab nilai rata-rata lebih besar dari nilai standar deviasinya.

Uji validitas merupakan digunakan untuk mengukur sah atau valid tidaknya kuesioner (Ghozali, 2016 : 52).

Dari hasil perhitungan uji validitas religiusias, pemahaman perpajakan, status social ekonomi, love of money dan persepsi penggelapan pajak seluruh nilai rhitung lebih besar dari pada rtabel pada jumlah sampel $\mathrm{N}$ sebanyak 81, karena itu dapat disimpulkan bahwa semua pertanyaan yang diuji dalam penelitian ini adalah valid, sehingga semua pertanyaan dari variabel kepatuhan wajib pajak dapat digunakan sebagai instrumen penelitian. 
Uji reliabilitas merupakan alat untuk mengukur suatu kuesioner yang merupakan indikator dari variabel atau konstruk ( Ghozali, 2016 : 47-48).

Tabel 4.2. Uji Reliabilias

\begin{tabular}{|c|c|c|c|}
\hline Jenis Kuesioner & R hitung & Nilai Corbanch's Alpha & Status \\
\hline Penggelapan Pajak & 0,749 & 0,70 & Reliabel \\
\hline Religiusitas & 0,701 & 0,70 & Realiabel \\
\hline Pemahaman Perpajakan & 0,805 & 0,70 & Reliabel \\
\hline Status Sosial Ekonomi & 0,938 & 0,70 & Reliabel \\
\hline Love Of Money & 0,840 & 0,70 & Reliabel \\
\hline
\end{tabular}

Sumber : Olah Data SPSS Versi 22

Dari hasil perhitungan reliabilitas religiusias, pemahaman perpajakan, status social ekonomi, love of money dan persepsi penggelapan pajak menghasilkan nilai Rhitung lebih besar dari nilai 0,70. Dengan demikian, kuesioner tersebut dapat digunakan sebagai instrument penelitian.
4.4 Analisis Regresi Linier Berganda menurut Deddy (2018 : 66), adalah analisis regresi linear yang digunakan untuk mengetahui pengaruh satu atau lebih variabel bebas (independen) terhadap satu variabel terikat (dependen). Adapun rumus dari model regresi linear berganda adalah sebagai berikut :

$\hat{\mathbf{Y}}=\alpha+\beta 1 \mathrm{X} 1+\beta 2 \mathrm{X} 2+\beta 3 \mathrm{X} 3+\beta 4 \mathrm{X} 4$ $+\beta 5 X 5+\varepsilon$

Tabel 4.3 Analisis regresi linier bergand

Coefficients $^{\mathrm{a}}$

\begin{tabular}{|c|c|c|}
\hline & $\begin{array}{l}\text { Unstandardiz } \\
\text { Coefficients }\end{array}$ & zed \\
\hline Model & B & Std. Err \\
\hline (Constant) & 2,636 & 2,621 \\
\hline RELIGIUSITAS &, 014 &, 065 \\
\hline $\begin{array}{l}\text { PEMAHAMAN } \\
\text { PERPAJAKAN }\end{array}$ & $-1,322$ &, 133 \\
\hline $\begin{array}{l}\text { STATUS SOSIAL } \\
\text { EKONOMI }\end{array}$ &,- 100 &, 256 \\
\hline $\begin{array}{ll}\text { LOVE } & \text { OF } \\
\text { MONEY } & \end{array}$ & 1,071 &, 084 \\
\hline
\end{tabular}

$$
\begin{array}{l|l|l|}
\begin{array}{l}
\text { Standardized } \\
\text { Coefficients } \\
\text { Beta }
\end{array} & \multicolumn{1}{|l}{\text { T }} & \text { Sig. } \\
& 1,006 & , 318 \\
, 014 & , 220 & , 827 \\
-1,503 & -9,907 & , 000 \\
-, 024 & -, 390 & , 698 \\
1,938 & 12,678 & , 000
\end{array} \mid
$$

Sumber : Olah Data SPSS Versi 22

Berdasarkan tabel diatas, dapat dilihat nilai constanta sebesar 2,636, koefisien religiusitas sebesar 0,14 , koefisien pemahaman perpajakan sebesar 1,322 , koefisien status sosial ekonomi sebesar -0,100 dan koefisien love of money sebesar 1,071. Dengan demikian dapat ditulis persamaan regresi menjadi bentuk persamaan sebagai berikut :

$$
\begin{gathered}
\mathrm{Y}=2,636+0,014 \mathrm{X} 1-1,322 \mathrm{X} 2- \\
0,100 \mathrm{X} 3+1,071 \mathrm{X} 4+\mathrm{e}
\end{gathered}
$$

4.5 Uji Simultan (Uji Statistik F) pada dasarnya menunjukkan apakah semua variabel independen atau bebas dalam model terdapat pengaruh terhadap variabel dependen atau terikat secara bersama-sama. Untuk dapat mengetahui variabel independen mempengaruhi secara bersama-sama variabel dependen 
maka digunakan tingkat signifikansi sebesar 0,05. Adapun kriteria diterima atau ditolaknya hipotesis sebagai berikut:

Jika nilai signifikan $<0,05$, maka hipotesis diterima (koefisien regresi signifikan). Hal ini menunjukkan bahwa variabel independen ber- pengaruh signifikan terhadap variabel dependen.

Jika nilai signifikan $>0,05$, maka hipotesis ditolak (koefisien regresi tidak signifikan). Hal ini menunjukkan bahwa variabel dependen tidak berpengaruh signifikan terhadap variabel independen.

Tabel 4.4. Uji Simultan (Uji F)

\begin{tabular}{|c|c|c|c|c|c|}
\hline $\begin{array}{l}\text { Model } \\
\text { Regression }\end{array}$ & $\begin{array}{l}\text { Sum of Squares } \\
510,196\end{array}$ & $\begin{array}{l}\mathrm{Df} \\
4\end{array}$ & $\begin{array}{c}\text { Mean } \\
\text { Square } \\
127,549\end{array}$ & $\begin{array}{l}F \\
45,022\end{array}$ & $\begin{array}{l}\text { Sig. } \\
, 000^{\mathrm{b}}\end{array}$ \\
\hline Residual & 215,310 & | 76 & 2,833 & & \\
\hline Total & 725,506 & 80 & & & \\
\hline
\end{tabular}

a. Dependent Variable: PENGGELAPAN PAJAK

b. Predictors: (Constant), LOVE OF MONEY, STATUS SOSIAL EKONOMI, RELIGIUSITAS, PEMAHAMAN PERPAJAKAN

Sumber : Olah Data SPSS Versi 22

Hasil pengujian hipotesis pengaruh religiusitas, pemahaman perpajakan, status social ekonomi dan love of money terhadap persepsi penggelapan pajak pada tabel 4.4 yang mana tertera nilai signifikansi sebesar 0,000 atau $<0,05$. Jadi dapat disimpulkan bahwa hipotesis diterima karena nilai signifikan 0,000. Sehingga pemanfaatan religiusitas, pemahaman perpajakan, status social ekonomi dan love of money berpengaruh secara simultan atau bersama-sama terhadap persepsi penggelapan pajak.

Uji Uji Parsial (Uji Statistik t) pada dasarnya menunjukkan seberapa jauh pengaruh satu variabel independen secara individual dalam menerangkan variasi variabel dependen. Pada penelitian ini pengujian dengan menggunakan signifikansi level 0,005 ( $\alpha$ $=5 \%$ ). Adapun kriteria diterima atau ditolaknya hipotesis sebagai berikut:

Jika nilai signifikan $<0,05$ maka hipotesis diterima. Hal ini menunjukkan bahwa variabel independen berpengaruh secara signifikan terhadap variabel dependen.

Jika nilai signifikan $>0,05$ maka hipotesis ditolak. Hal ini menunjukkan variabel dependen tidak berpengaruh secara signifikan terhadap variabel independen.

Tabel 4.5. Uji Parsial (Uji t)

Coefficients $^{\mathrm{a}}$

\begin{tabular}{|c|c|c|c|c|c|}
\hline \multirow[t]{2}{*}{ Model } & \multicolumn{2}{|c|}{$\begin{array}{c}\text { Unstandardized } \\
\text { Coefficients }\end{array}$} & $\begin{array}{r}\text { Standardized } \\
\text { Coefficients }\end{array}$ & \multirow[t]{2}{*}{$\mathrm{T}$} & \\
\hline & B & Std. Error & Beta & & \\
\hline \multirow{5}{*}{$\begin{array}{l}\text { (Constant) } \\
\text { RELIGIUSITAS } \\
\text { PEMAHAMAN } \\
\text { PERPAJAKAN } \\
\text { STATUS SOSIAL EKONOMI } \\
\text { LOVE OF MONEY }\end{array}$} & 2,636 & 2,621 & & 1,006 & ,318 \\
\hline & ,014 &, 065 &, 014 & ,220 &, 827 \\
\hline & $-1,322$ & ,133 & $-1,503$ & $-9,907$ & ,000 \\
\hline &,- 100 & ,256 &,- 024 &,- 390 & ,698 \\
\hline & 1,071 &, 084 & 1,938 & 12,678 &, 000 \\
\hline
\end{tabular}

a. Dependent Variable: PENGGELAPAN PAJAK Sumber : Olah Data SPSS Versi 22 
Berdasarkan data yang terdapat dalam tabel 4.5 diperoleh suatu kesimpulan sebagai berikut :

Hipotesis yang menyatakan bahwa diduga terdapat pengaruh signifikan religiusitas terhadap penggelapan pajak tidak terbukti, dengan nilai signifikan $0,827>0,05$ maka hipotesis ditolak

Hipotesis yang menyatakan bahwa diduga terdapat pengaruh signifikan pemahaman perpajakan terhadap penggelapan pajak terbukti, dengan nilai signifikan $0,000<0,05$ maka hipotesis diterima.

Hipotesis yang menyatakan bahwa diduga terdapat pengaruh signifikan status sosial ekonomi terhadap penggelapan pajak tidak terbukti, dengan nilai signifikan $0,698>0,05$ maka hipotesis ditolak
Hipotesis yang menyatakan bahwa diduga terdapat pengaruh signifikan love of money terhadap penggelapan pajak terbukti, dengan nilai signifikan $0,000<0,05$ maka hipotesis diterima.

Koefisien Determinasi pada hakekatnya mengukur seberapa besar kemampuan persamaan model dalam menerangkan variasi yang terdapat pada variabel dependen. Nilai $R^{2}$ terletak antara 0 sampai $1\left(0 \leq \mathrm{R}^{2} \leq\right.$ 1). Koefisien determinasi dapat dihitung untuk mengetahuI pengaruh variabel independen terhadap variabel dependen. Jika proses mendapatkan nilai $\mathrm{R}^{2}$ yang tinggi adalah baik, tetapi jika nilai $\mathrm{R}^{2}$ rendah bukan berarti model regresi jelek (ghozali, 2016 : 95). Adapun tabel hasil koefisien determinasi sebagai berikut :

Tabel 4.6 Koefisien Determinasi

\begin{tabular}{|c|c|c|c|c|}
\hline \multicolumn{5}{|c|}{ Model Summary } \\
\hline Model & $\mathrm{R}$ & R Square & $\begin{array}{l}\text { Adjusted R } \\
\text { Square }\end{array}$ & Std. Error of the \\
\hline 1 &, $839^{\mathrm{a}}$ & ,703 & ,688 & 1,68316 \\
\hline
\end{tabular}

a. Predictors: (Constant), love of money, status sosial ekonomi, religiusitas, pemahaman perpajakan

b. Dependent Variable: penggelapan pajak Sumber : Olah Data SPSS Versi 22

Berdasarkan tabel 4.6, didapat nilai koefisien determinasi sebesar 0,688 atau $68,8 \%$. Hal ini manunjukkan bahwa variabel penggelapan pajak dipengaruhi oleh variabel religiusitas, pemahaman perpajakan, status sosial ekonomi dan love of money sebesar $68,8 \%$. Sedangkan sisanya $31,2 \%$ dipengaruhi oleh faktor lain yang tidak dijelaskan dalam penelitian ini.

\section{KESIMPULAN DAN SARAN}

\section{Kesimpulan}

Berdasarkan hasil analisis data dan pembahasan yang telah dilakukan, maka dapat disimpulkan bahwa :
Religiusitas, pemahaman perpajakan, status sosial ekonomi dan love of money secara simultan berpengaruh terhadap persepsi penggelapan pajak pada mahasiswa akuntansi Fakultas Ekonomi dan Bisnis Universitas Pancasakti Tegal.

Religiusitas (X1) secara parsial tidak berpengaruh terhadap persepsi penggelapan pajak pada mahasiswa akuntansi Fakultas Ekonomi dan Bisnis Universitas Pancasakti Tegal.

Pemahaman perpajakan (X2) secara parsial berpengaruh terhadap persepsi penggelapan pajak pada mahasiswa 
akuntansi Fakultas Ekonomi dan Bisnis Universitas Pancasakti Tegal

Status sosial ekonomi (X3) secara parsial tidak berpengaruh terhadap persepsi penggelapan pajak pada mahasiswa akuntansi Fakultas Ekonomi dan Bisnis Universitas Pancasakti Tegal.

$$
\begin{aligned}
& \text { Love of money (X4) secara parsial } \\
& \text { berpengaruh terhadap persepsi } \\
& \text { penggelapan pajak pada mahasiswa } \\
& \text { akuntansi Fakultas Ekonomi } \\
& \text { Universitas Pancasakti Tegal. }
\end{aligned}
$$

\section{Saran}

Berdasarkan kesimpuan yang telah diuraiakan tersebut, maka peneliti dapat memberikan saran-saran sebagai berikut:

Secara simultan religiusitas, pemahaman perpajakan, status sosial ekonomi dan love of money secara simultan berpengaruh terhadap persepsi penggelapan pajak pada mahasiswa akuntansi. Oleh karena itu, fakultas ekonomi dan bisnis harus menekankan pembelajaran tentang perpajakan kepada mahasiswa fakultas ekonomi dan bisnis agar nantinya mahasiswa yang telah dinyatakan lulus tidak melakukan tindakan negative seperti penggelapan pajak.

Religiusitas secara parsial tidak berpengaruh terhadap persepsi penggelapan pajak pada mahasiswa akuntansi Fakultas Ekonomi dan Bisnis. Oleh karena itu, fakultas ekonomi dan bisnis harus dapat mempertahankan tingkat religiusitas tersebut.

Pemahaman perpajakan secara parsial berpengaruh terhadap persepsi penggelapan pajak pada mahasiswa akuntansi Fakultas Ekonomi dan Bisnis. Oleh karena itu fakultas ekonomi dan bisnis harus lebih meningkatkan kembali materi perpajakan kepada mahasiswa agar tingkat pemahaman perpajakan jauh lebih baik dari sebelumnya.

Love of money secara parsial berpengaruh terhadap persepsi penggelapan pajak pada mahasiswa akuntansi Fakultas Ekonomi Universitas Pancasakti Tegal. Oleh karena itu, fakultas ekonomi dan bisnis harus lebih meningkatkan kembali materi akuntansi keuangan agar mahasiswa lebih memahami materi tersebut dan dapat menggunakan uang sebagai mana mestinya.

Untuk peneliti selanjutnya diharapkan dapat mengambil sampel yang lebih besar dan menambah jumlah responden yang akan diteliti untuk dapat melihat pengaruhnya terhadap persepsi penggelapan pajak. Bila perlu menambahkan variabel independen lainnya yang dapat mempengaruhi persepsi penggelapan pajak yang belum diteliti pada penelitian ini.

\section{DAFTAR PUSTAKA}

Ardiansyah, Yuli. 2017. "Pengaruh keadilan, Sistem Self Assessment, Pemahaman Perpajakan dan Religiuaitas Terhadap Tindakan Tax Evasion". Skripsi. Makassar. Universitas Hasanuddin Makassar. (Dipublikasikan)

Aziz, Toriq Ibnu. 2015. "Pengaruh Love Of Money dan Machiaviellan Terhadap Persepsi etis Mahasiswa Akuntansi" Skripsi. Yogyakarta. Universitas Negeri Yogyakarta. (Dipublikasikan) 
Bahari, Nisa Arifiani Permata. 2016. "Pengaruh Pemahaman Perpajakan, Sistem Perpajakan, Persepsi Pada Pihak Fiskus Dan Keadilan Terhadap Tindakan Tax Evasion". Skripsi. Yogyakarta. Universitas Negeri Yogyakarta. (Dipublikasikan)

Basri, Yesi Mutia. 2015. "Pengaruh gender, religiusitas dan sikap love of money pada persepsi etika penggelapan pajak mahasiswa akuntansi". Jurnal Ilmiah Akuntansi dan Bisnis, Vol. 10, No. 1, Hal. 45

Dharma, Lasmia. 2016. "Pengaruh gender, pemahaman perpajakan dan religiusitas terhadapn persepsi penggelapan pajak". JOM Fekon, Vol. 3, no. 1

Fakih, Mansour. 2007. Gender \& Pembangunan. Yogyakarta : Rifka Annisa Women's Crisis Centre Gunadi. 2016. PanduanKomprehensifKetentuanUmumPerpajakan (KUP). Jakarta : Bee Media Indonesia Ghozali, Imam. 2016. Aplikasi Analisis Multivariete dengan Program IBM SPSS 23. Semarang: Badan Penerbit Universitas Diponegoro

Hafizhah, Ihsanul. 2016. "Pengaruh Etika Uang (Money Ethics) Terhadap Kecurangan Pajak (Tax Evasion) Dengan Religiusitas, Gender dan Materealisme Sebagai Variabel Moderasi”. JOM FEKON. Vol. 3, No. 1, Hal. 1652.

HanTer. 2016, 24 Oktober. Jokowi Harus Turun Tangan Tuntaskan Penggelapan Pajak Asian Agri. Harian Terbit. Online. https://m.harianterbit.com/welcome/ (20 Maret 2018)

Isroah, Hutama Dan Amanita Novi Yusita. 2016. "Persepsi Etika Dalam Penggelapan Pajak : Bukti Persepsi Pada Fakultas Ekonomi, Universitas Negeri Yogyakarta". Jurnal Pendidikan Akuntansi Indonesia. Vol. XIV, No. 2, Hal. 80.

Kuswanti, Heni. 2016, 16 Februari. Kriteria Status Sosial ekonomi. dKampus. Online. https://www.dkampus.com/2016/02/konsep-dan-kriteria-status-sosial-ekonomi/ (03 Maret 2018)

Mardiasmo. 2013. Perpajakan edisi revisi. Yogyakarta : CV. Andi Offset

Nopdrr. 2015, 1 Desember. Psikologi: Pengertian Persepsi dan Faktor Yang Mempengaruhi Persepsi. Nop

(Nursing Student). Online. http://nopdrr.mahasiswa.unimus.ac.id/ 2015/12/01/psikologipersepsi/ (03 Maret 2018)

Oentoro, Reydho Dwi Septyawan. 2016. "Pengaruh Money Ethics terhadap Kecurangan Pajak Dengan

Normalitas Sebagai Variabel Moderasi”. Skripsi. Bengkulu. Universitas bengkulu. (Dipublikasikan)

Purnamaningsih, Ni Ketut Ayu dan Dodik Ariyanto. 2016. "Pengaruh gender, usia, tingkat pendidikan dan status sosial ekonomi terhadap persepsi etis mahasiswa akuntansi”. E-Jurnal Akuntansi Universitas Udayana, Vol. 17, No. 2, hal. 996

Rahayu, Sitikurnia. 2010. Perpajakan Indonesia KonsepdanAspekPerpajakan. Yogyakarta: GrahaIlmu

Rahayu, Sitikurnia. 2017. Perpajakan (Konsepdan Aspek Perpajakan). Bandung: RekayasaSains 
Reskino, Rini dan Dinda Novitasari. 2014. "Persepsi mahasiswa akuntansi mengenai penggelapan pajak". Jurnal Infestasi, Vol. 10, No. 1, Hal. 49

Resmi, Siti. 2014. PerpajakanTeoridanKasus. Jakarta :SalembaEmpat

Robbins, Stephen P. 2001. Perilaku Organisasi (konsep, kontroversi, aplikasi) edisi kedelapan.

Rosianti, Camelia dan Yenny Mangoting. 2014. "Pengaruh money ethics terhadap tax evasion dengan intrinsic dan extrinsic religiosity sebagai variabel moderating". Tax \& Accounting review, Vol. 4, No. 1, Hal. 1

Salam, Burhanuddin. 1997. Etika Sosial (Asas Moral Dalam Kehidupan Manusia). Jakarta : PT Rineka Cipta

Shabrina, Reza. 2017, 27 juli. 10 Pengertian Persepsi Menurut Para Ahli. Dosenpsikologi.com. Online. https://dosenpsikologi.com/pengertian-persepsimenurut-para-ahli(03 Maret 2018)

Soedarwo, Vina Salviana D. Dan Tutik Sulistyowati. 2016. Sosiologi Gender. Tangerang Selatan: Universitas Terbuka.

Sugiyono. 2016. MetodePenelitianAdministrasi. Bnadung :Alfabeta

Sumarsan, Thomas. 2015. Perpajakan Indonesia (Pedoman Perpajakan Lengkap Berdasarkan Undang-Undang Terbaru)Edisiempat. Jakarta : PT. Indeks

Uma, Hasminee. 2013, 20 Oktober. Persepsi: Pengertian, Definisi, dan Faktor Yang Mempengaruhi. Kompasiana. Online. https://www.kompasiana.com/hasminee/ (03 Maret 2018)

Wicaksono, Adhi. 2016, 23 November. Rentetan Kasus Korupsi Yang menjerat Pegawai Pajak. CNN Indonesia. https://m.cnnindonesia.com/nasional/ (20 Maret 2018)

Wicaksono, Muhammad Ary. 2014. "pengaruh Persepsi Sistem Perpajakan, Keadilan Pajak, Diskriminasi Pajak dan Pemahaman Perpajakan Terhadap Perilaku Penggelapan Pajak". Skripsi. Semarang. Universitas Diponegoro. (Dipublikasikan)

Yuniar, Ery Susanti. 2010. "Pengaruh Sensitivitas Etika, Umur dan Gender Terhadap Persepsi Etika Atas Tax

Evasion". Skripsi. Surakarta. Universitas Negeri Sebelas Maret. (Dipublikasikan)

Zirman. 2015. "Pengaruh penegakan hukum dan gender terhadap penggelapan pajak dimediasi oleh moral pajak". Akuntabilitas, Vol. VIII, No. 2, Hal. 133 